УДК 334.02

DOI: https://doi.org/10.37320/2415-3583/7.11

Смоляр Л.Г.

кандидат економічних наук, професор, ректор, Міжнародний університет фінансів професор кафедри менеджменту,

Національний технічний університет Украӥни «Київський політехнічний інститут імені Ігоря Сікорського»

Трофименко О.O.

кандидат економічних наук, доцент, доцент кафедри економіки та підприємництва,

Міжнародний університет фінансів доцент кафедри теоретичної та прикладної економіки, Національний технічний університет Украйни «Київський політехнічний інститут імені Ігоря Сікорського»

\title{
ТРАНСФОРМАЦІЯ СФЕРИ ВІДНОВЛЮВАНОЇ ЕНЕРГЕТИКИ НА ОСНОВІ УПРАВЛІННЯ ЗНАННЯМИ
}

У статті досліджено тендениії розвитку відновлюваної енергетики та особливості управління знаннями в иій сфері. Досліджено структуру виробництва електроенергії від різних джерел генерації. Проаналізовано динаміку енергоспоживання на основі відновлюваних джерел з 2007 по 2018 рр. Визначено, щзо об'єкти вітрових енергетичних систем та сонячних енергетичних систем склали понад 99\% введених потужностей за рахунок відновлюваних джерел енергії у I кварталі 2019 р. Відзначено зростання кількості підприємств у сфері відновлюваної енергетики, щзо потребує впровадження підходів до управління знаннями для їх подальшого розвитку. Визначено основні аспекти забезпечення управління знаннями на підприємствах відновлюваної енергетики, щцо обумовлені галузевими особливостями функиіонування цих підприємств. Надано приклади наукових, технологічних та управлінських знань у сфері відновлюваної енергетики. Визначено, охарактеризовано основні драйвери для забезпечення ефективності управління знаннями на підприємствах відновлюваної енергетики.

Ключові слова: управління знаннями, відновлювана енергетика, розвиток підприємств.

Постановка проблеми. Розвиток відновлюваної енергетики є одним з пріоритетних завдань відповідно до прийнятої Енергетичної стратегії України на період до 2035 р. «Безпека, енергоефективність, конкурентоспроможність» [1]. Водночас на глобальному рівні до 2030 р. поставлені завдання щодо збільшення частки енергії з відновлюваних джерел у світовому енергетичному балансі, активізації міжнародного співробітництва задля полегшення доступу до досліджень i технологій у галузі екологічно чистої енергетики, включаючи відновлювану енергетику. Ці завдання поставлені в межах Глобальних Цілей сталого розвитку до 2030 р., затверджених на саміті ООН з питань сталого розвитку, а саме Ціль 7 «Доступна та чиста енергія», сьогодні вони набувають підтримки та вирішуються на державному рівні в Україні [2]. Також у межах угоди між Україною та ЄС, прийнятої Рамковою Конвенцією Організації Об'єднаних Націй про зміну клімату (UNFCCC) у Парижі у 2015 р. [3], існує домовленість зі сторонами UNFCCC про необхідність виконання вимог цієї Конвенції та впровадження механізмів Кіотського протоколу до неї, зокрема щодо реалізації проєктів, спрямованих на охорону навколишнього природного середовища. Все це сприяє зростанню проєктів з відновлюваної енер- гетики та збільшенню кількості підприємств, які займаються їх впровадженням в Україні.

Водночас досвід європейських країн 2000-2019 pр. [3; 4; 5; 6] свідчить про те, що для розвитку підприємств відновлюваної енергетики потрібно застосовувати спеціалізовані підходи до управління знаннями на цих підприємствах, впроваджувати та розвивати відповідні технології менеджменту знань, які враховують галузеві особливості розвитку відновлюваної енергетики та впливають на стратегічний інноваційний розвиток цих підприємств.

Саме тому сьогодні для таких підприємств в Україні важливо формувати засади та механізми управління знаннями для того, щоби реалізовувати проєкти 3 відновлюваної енергетики, підвищувати рівень їх ефективності та конкурентоспроможності.

Аналіз останніх досліджень і публікацій. Серед досліджень основних питань з управління знаннями загалом і менеджменту знань в енергетичному секторі зокрема можна виділити праці таких учених, як Е. Айола, Є. Демінг, Дж. Джуран, Дж. Едвордс, Ф. Кросбі, А. Фейгенбаум, М. Уейт.

Визнаючи вагомий внесок учених у розвиток досліджуваної проблематики, бачимо, що залишаються недостатньо визначеними деякі аспекти 
управління знаннями в країнах, які віднесені до групи країн Нової Свропи, яка розвивається [7], зокрема не досліджені особливості управління знаннями на підприємствах відновлюваної енергетики в Україні.

Мета статті полягає у визначенні тенденцій розвитку відновлюваної енергетики та особливостей управління знаннями на підприємствах у цій сфері.

Виклад основного матеріалу. Виробництво електроенергії з відновлюваних джерел за січеньтравень 2019 р. склало 2441 млн. кВт/год., що становить 3,34\% від загального обсягу генерації, a саме 73042 млн. кВт/год. [8; 9]. Для порівняння частки виробництва електроенергії від різних джерел генерації наведено на рис. 1.

За результатами аналізу маємо те, що за 11 років спостерігалися суттєві зміни в енергоспоживанні на основі відновлюваних джерел енергії (рис. 2). Відзначимо, що представлені дані з енергоспоживання на основі відновлюваних джерел енергії конкретно за 2014-2018 рр. не враховують показники тимчасово окупованих територій Автономної Республіки Крим і м. Севастополя та частини тимчасово окупованих територій у Донецькій та Луганській областях. Так, з 2011 р. по 2014 р. спостерігалося зростання енергоспоживання на основі енергії вітру та сонця на 124 тис. т. н. е. 32014 р. по 2016 р. відбувається зменшення енергоспоживання на основі енергії вітру та сонця на 7,5\%, проте з 2016 р. по 2018 р. зростає майже на $59 \%$.

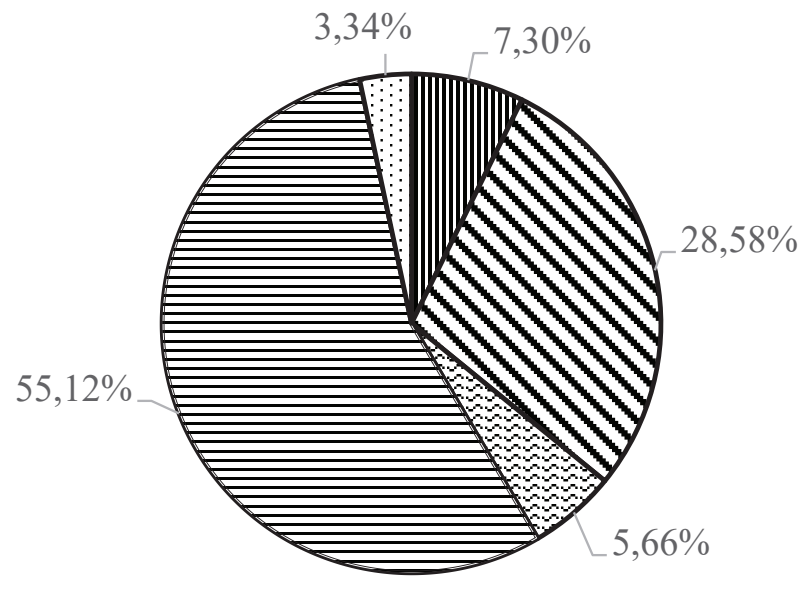

\section{田ТЕЦ та ін. $\mathbf{\top}$}

Рисунок 1 - Структура виробництва електроенергії від різних джерел генерації за січень-травень 2019 р.

У I кварталі 2019 р. було введено в експлуатацію 861,1 МВт генеруючих потужностей за рахунок відновлюваних джерел енергії, що на $16 \%$ більше, ніж за весь 2018 р., об'єкти ВЕС і СЕС склали 99,5\% введених потужностей. У І кварталі 2019 р. НКРЕКП встановила «зелений» тариф для 67 об'єктів електроенергетики (серед яких СЕС становлять 58 об'єктів, ВЕС - 4 об'єкти, біогаз/ біомаса - 4 об'єкти, малі ГЕС - 1 об'єкт). Середня одинична потужність введених в експлуатацію в

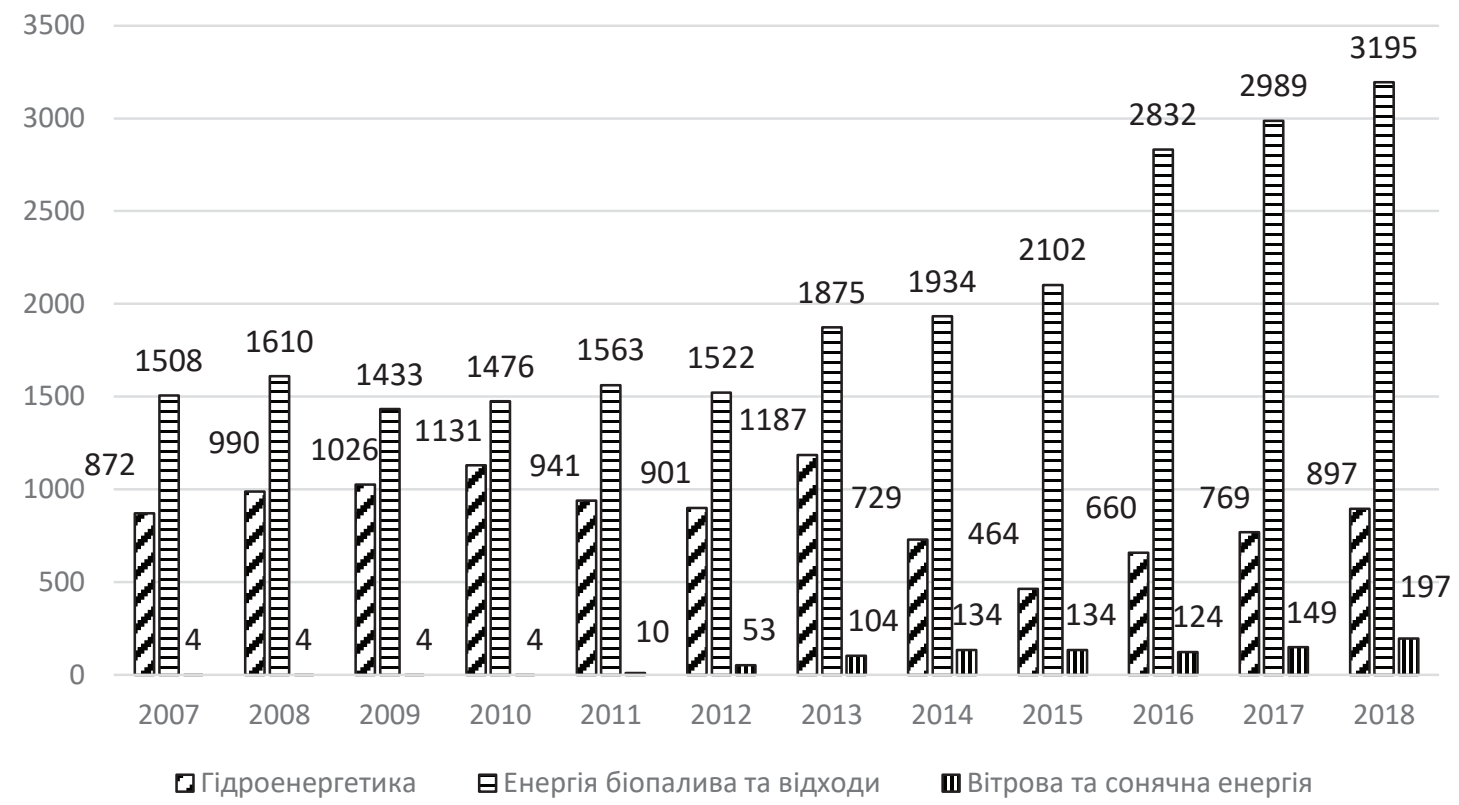

Рисунок 2 - Динаміка енергоспоживання на основі відновлюваних джерел енергії за 2007-2018 рр., тис. т. н. е.

Джерело: розроблено на основі джерела [10] 
I кварталі 2019 р. об'єктів електроенергетики становить 11,8 МВт, а лідером із введення в експлуатацію об' єктів ВДЕ в I кварталі 2019 р. є Дніпропетровська область (258,6 МВт) [11].

Сьогодні в Україні функціонує близько 240 підприємств у сферах відновлюваної енергетики та енергоефективності, що у сукупності з результатами галузі загалом свідчить про важливість забезпечення всебічної підтримки їх розвитку.

Так, у Меморандумі про взаєморозуміння щодо Стратегічного Енергетичного Партнерства між Україною та ЄС спільно з Європейським Співтовариством з атомної енергії [12] зазначено необхідність розвитку енергетичної інфраструктури України та реалізації проєктів, спрямованих на поглиблення іiї інтеграції в енергетичну інфраструктуру $\mathrm{CC}$, сформовано засади співробітництва стосовно залучення інвестицій та фінансування.

Це у сукупності з Енергетичною стратегією України закладає фундамент розвитку відновлюваної енергетики на макрорівні. Водночас особливості цієї сфери обумовлюють потреби підприємств щодо побудови відповідної системи управління знаннями для ефективної роботи таких підприємств, адже знання $є$ центральною ланкою в оперативній та стратегічний діяльності підприємств сектору відновлюваної енергетики та надходять у різних формах, таких як наукові знання (наприклад, принцип фотовальтаїки), технологічні знання (наприклад, як ефективно використовувати вітрові генератори), управлінські знання (наприклад, як мотивувати своїх співробітників впроваджувати нові методи роботи) [13]

Міжнародна організація зі стандартизації ISO [14] опублікувала понад 50 стандартів для систем сонячної енергії та біопалива, зокрема стандарти ефективності, сонячне нагрівання, сонячні панелі та тверде біопаливо. Основні сфери розроблення стандартів 3 відновлюваної енергетики наведено в табл. 1.

Відповідно до концепції управління знаннями можна виділити такі поняття: «драйвери (рушії)», «перешкоди та ключові фактори успіху», а також визначити основні напрями їх застосування на підприємствах у сфері відновлюваної енергетики.

Першим з основних рушіїв $є$ створення знань. Створення знань - це складний процес, який потребує розвиненого критичного мислення, особистої взаємодії та достатнього часу для адекватного розвитку. Так, наприклад, у проєкті Offshore Wind Accelerator (OWA), де співпрацюють організації "Carbon Trust" та міжнародні енергетичні компанії сфери відновлюваної енергетики "DONG Energy", "E.ON", "Mainstream Renewable Power", "RWE Innogy", "Scottish Power Renewables", "SSE Renewables", "Statkraft", "Statoil i Vattenfall" [4], проблеми та рішення від-
Таблиця 1 - Напрями застосування стандартів ISO у сфері відновлюваної енергетики

\begin{tabular}{|c|c|}
\hline $\begin{array}{c}\text { Технічні комітети } \\
\text { Міжнародної } \\
\text { організації зі } \\
\text { стандартизації } \\
\end{array}$ & $\begin{array}{c}\text { Напрями розроблення } \\
\text { стандартів у сфері } \\
\text { відновлюваної енергетики }\end{array}$ \\
\hline ISO/TC 180 & Сонячна енергія \\
\hline ISO/TC 238 & Тверде біопаливо \\
\hline ISO/TC 301 & $\begin{array}{l}\text { Енергетичний менеджмент та } \\
\text { енергозбереження }\end{array}$ \\
\hline ISO/TC 205 & Дизайн екологічних будівель \\
\hline ISO/TC 197 & Водневі технології \\
\hline ISO/TC 184 & $\begin{array}{l}\text { Системи автоматизації та } \\
\text { інтеграції }\end{array}$ \\
\hline ISO/TC 117 & Промислові вентилятори \\
\hline ISO/TC 115 & Насоси \\
\hline ISO/TC 207 & Екологічний менеджмент \\
\hline ISO/TC 163 & $\begin{array}{l}\text { Теплові показники та } \\
\text { використання енергї̈ довкілля }\end{array}$ \\
\hline ISO/TC 265 & $\begin{array}{l}\text { Уловлювання, } \\
\text { транспортування та геологічне } \\
\text { зберігання вуглекислого газу }\end{array}$ \\
\hline ISO/IEC JTC 1/SC 39 & $\begin{array}{l}\text { Інформаційні технології для } \\
\text { забезпечення сталого розвитку }\end{array}$ \\
\hline ISO/TC 22/SC 37 & $\begin{array}{l}\text { Електричні транспортні } \\
\text { засоби }\end{array}$ \\
\hline
\end{tabular}

Джерело: узагальнено автором на основі джерела [14]

крито обговорюються технічними робочими групами, які мають спеціальний досвід у відповідних технічних сферах. Також команда управління OWA Carbon Trust цілеспрямовано проводить засідання Керівного комітету через регулярні проміжки часу, щоби керівники ухвалили остаточні рішення щодо проєктів і загального спрямування іiї інноваційної програми після взаємодії 3 колективом. Це також має наслідки для досліджень щодо інноваційних програм підприємств відновлюваної енергетики, адже потрібні інтерактивні процеси, що полегшують співпрацю, на відміну від жорстких структур у командах і групах, що притаманні багатьом підприємствам традиційної промисловості в Україні.

Другий рушій, що використовується в міжнародних компаніях відновлюваної енергетики, - це пошук знань. Важливо формувати систему управління зовнішніми мережами, що може бути ефективним способом інформування про зовнішні зміни, які можуть вплинути на процеси та результати діяльності організації чи реалізацію програми. Наприклад, у межах проєкту OWA успішно відбувалося керівництво зовнішніми мережами, проводилися конкурси із залучення інноваційних концепцій з усього світу додатково до постійного контакту з урядовцями, науковцями, інститутами, університетами тощо [4]. Важливо розвивати стосунки 3 учасниками зовнішніх мереж, які надають довгострокові та часто неочікувані переваги. 
Третім рушієм, що спонукає широке коло як науковців, так і практиків звертатися до управління знаннями, - це зберігання знань. Існує низка досліджень, де сформовані методології зі зберігання знань за допомогою IT-інструментів. Водночас IT-інструменти можуть створювати лише сховища інформації та $є$ засобом для пізнання, а не власне знанням, тобто на основі інформації, отриманої з використанням IT та аналізом даних, можна отримати знання. Для зберігання знань також використовуються різні корпоративні сервіси. Дослідження можуть отримати користь від розуміння того, що IT-інструменти треба використовувати там, де очікується високий ефект від їх використання.

Четвертим рушієм управління знаннями $\epsilon$ обмін знаннями. Завдяки постійній взаємодії та прозорості, а також заохоченню взаємодії партнерів у командах ефективність від обміну знаннями зростає. Водночас обмін знаннями може бути досить складним процесом, де важливо визначити, яке знання ділиться, яке ні, чому.

П'ятим рушієм управління знаннями в рамках інноваційних проєктів $є$ організаційне навчання. Організаційне навчання є одним 3 ключових знаннєутворюючих елементів системи управління підприємства, яке в межах окремої компанії може бути реалізоване п'ятьма базовими циклами формування та розвитку професійних компетенцій фахівця, такими як корпоративне навчання, професійні співтовариства, наставництво, коучинг, самонавчання [15].

Також варто зазначити, що сучасний менеджер проєктів 3 відновлюваної енергетики має володіти відповідним професійним інструментарієм у сфері проєктного менеджменту, енергетиці та конкретно відновлюваній енергетиці (відповідно до міжнародних стандартів PMI PMCDF, GAPPS GL1/2, AIPM CPPP, APM Competence Framework, IPMA ICB 3.0, OGC PRINCE2TM, PMAJ P2M,
ISO 21500:2012, ISO 50001:2018 тощо), атрибутивними компетенціями (AttributeBased Inference визначає базові професійні компетенції щодо об'єкта/суб'єкта управління), спеціальними технічними/технологічними компетенціями (Performance-Based Inference визначає виконавчі компетенції), IT-засобами, достатнім рівнем компетенцій у процесному управлінні та аналітичній роботі, комунікативними та поведінковими компетенціями відповідного рівня [15]. Розвиток професійних компетенцій потребує від фахівця формування, підтримування в актуальному стані та розвитку комплексу знань, умінь, навичок, поглядів і моделей поведінки для забезпечення постійного та бажаного результату [15].

Висновки. Динаміка відновлюваної енергетики в Україні свідчить про іiі зростання. Так, у I кварталі 2019 р. було введено в експлуатацію 861,1 МВт генеруючих потужностей за рахунок відновлюваних джерел енергії, що на $16 \%$ більше, ніж за весь 2018 р., об'єкти ВЕС і СЕС склали 99,5\% введених потужностей. Потреба управління знаннями на підприємствах відновлюваної енергетики прямо пропорційна потребі на державному рівні розвивати сферу відновлюваної енергетики загалом, тому важливо досліджувати зарубіжний досвід управління проєктами в сфері відновлюваної енергетики задля застосування їх на українських підприємствах. Оскільки сфера відновлюваної енергетики належить до інноваційних, то це треба враховувати під час побудови системи управління знаннями на підприємстві. Загалом підходи до управління знаннями в інноваційній діяльності є універсальними, але потребують адаптації до конкретної галузі. Подальших розвідок потребує дослідження функціонуючих українських підприємств відновлюваної енергетики для проведення GAP-аналізу та формулювання практичних рекомендацій за результатами конкретних підприємств.

\section{Список використаних джерел:}

1. Енергетична стратегія України на період до 2035 року «Безпека, енергоефективність, конкурентоспроможність» : Розпорядження Кабінету Міністрів України від 18 серпня 2017 р. № 605-p. URL: http://zakon2.rada.gov.ua/laws/ show/605-2017-\%D1\%80 (дата звернення: 10.11.2019).

2. Цілі сталого розвитку в Україні // Міністерство економічного розвитку і торгівлі України : веб-сайт. URL: http://un.org.ua/images/SDGs_NationalReportUA_Web_1.pdf (дата звернення: 10.12.2019).

3. Рамкова конвенція. Організації Об'єднаних Націй про зміну клімату. URL: https://zakon.rada.gov.ua/laws/ show/995_044 (дата звернення: 20.10.2019).

4. Valuing Knowledge Assets in Renewable Energy SMEs: Some Early Evidence / M. Weir, R. Huggins, G. Schiuma, A. Lerro, D. Prokop. Electronic Journal of Knowledge Management. 2010. № 8. P. 225-234.

5. The Creative Economy: Key Concepts and Literature Review Highlights. Ottawa. URL: http://prinnovationhub.com/ wp-content/uploads/2018/08/creative-economy-synthesis_201305.pdf (дата звернення: 15.11.2019).

6. Ayoola A. Knowledge-Managing Sustainable Energy Schemes - An Innovative Approach. Journal of Clean Energy Technologies. 2015. № 3. P. 226-231.

7. World Economic Outlook Database. URL: https://www.imf.org/external/pubs/ft/weo/2019/02/weodata/index.aspx (дата звернення: 12.10.2019).

8. Державне підприємства «Енергоринок» : офіційний сайт. URL: http://www.er.gov.ua (дата звернення: 12.10.2019).

9. Виробництво електроенергії з відновлюваних джерел станом на 1 липня 2019 року. URL: http://uare.com.ua/ images/stat2019UARE06ukr.pdf; http://uare.com.ua/images/stat2019UARE06ukr.pdf (дата звернення: 12.10.2019). 
10. Державна служба статистики : офіційний сайт. URL: http://www.ukrstat.gov.ua (дата звернення: 01.10.2019).

11. НКРЕКП інформує про розвиток сектору ВДЕ у I кварталі 2019 року. URL: http://www.nerc.gov.ua/?news=8890 (дата звернення: 01.10.2019).

12. Меморандум про взаєморозуміння щодо Стратегічного Енергетичного Партнерства між Україною та Європейським Союзом спільно з Свропейським Співтовариством з атомної енергії : підписання від 24 листопада 2016 року. URL: http://zakon3.rada.gov.ua/laws/show/984 003-16 (дата звернення: 10.11.2019).

13. Edwards J. Knowledge management in the energy sector: Review and future directions. International Journal of Energy Sector Management. 2008. №2. P. 2-23.

14. ISO and energy. URL: https://www.iso.org/files/live/sites/isoorg/files/store/en/PUB100320.pdf (дата звернення: 01.10.2019).

15. Приймак В.М. Організаційне навчання в системі управління проектами. Економіка та управління підприємствами. 2018. С. 214-221.

\title{
References:
}

1. The Verkhovna Rada of Ukraine (2017), Energy Strategy of Ukraine for the period up to 2035 "Safety, Energy Efficiency, Competitiveness": Order of the Cabinet of Ministers of Ukraine dated August 18, 2017 No. 605-p, available at: http://zakon2.rada.gov.ua/laws/show/605-2017-\%D1\%80 (accessed: 10 November 2019).

2. Ministry of Economic Development and Trade of Ukraine (2017) Sustainable Development Goals: Ukraine. Available at: http://un.org.ua/images/SDGs_NationalReportUA_Web_1.pdf (accessed: 10.12.2019).

3. The Verkhovna Rada of Ukraine (1996), Framework Convention "The United Nations on climate change", available at: https://zakon.rada.gov.ua/laws/show/995_044 (accessed: 29 October 1996).

4. Weir, M., Huggins, R., Schiuma, G., Lerro, A. and Prokop, D. (2010), "Valuing Knowledge Assets in Renewable Energy SMEs: Some Early Evidence”. Electronic Journal of Knowledge Management, vol. 8, pp. 225-234.

5. The Powell River Creative Economy and Innovation Initiative (2018), "The Creative Economy: Key Concepts and Literature Review Highlights", available at: http://prinnovationhub.com/wp-content/uploads/2018/08/creative-economysynthesis_201305.pdf (accessed: 15 Nowember 2019).

6. Ayoola, A. (2015), "Knowledge-Managing Sustainable Energy Schemes - An Innovative Approach", Journal of Clean Energy Technologies, vol. 3, pp. 226-231.

7. IMF (2019), "World Economic Outlook Database", available at: https://www.imf.org/external/pubs/ft/weo/2019/02/ weodata/index.aspx (accessed: 12 October 2019).

8. The official site of State Company "Energorynok" (2019), "Electricity producers from alternative sources", available at: http://www.er.gov.ua (accessed: 12 October 2019).

9. Ukrainian association of renewable energy (2019), "Production of electricity from renewable sources as of 01.07.2019", available at: http://uare.com.ua/images/stat2019UARE06ukr.pdfhttp://uare.com.ua/images/stat2019UARE06ukr.pdf (accessed: 12 October 2019).

10. Ukrstat (2019), "Energy Consumption Based on Renewable Sources for 2007-2018", available at: http://www.ukrstat.gov.ua (accessed: 1 October 2019).

11. NKREKP (2019), "NKREKP inform the RES SECTOR DEVELOPMENT In I quarter 2019", available at: http://www.nerc.gov.ua/?news=8890 (accessed: 1 October 2019).

12. The Verkhovna Rada of Ukraine (2016), Memorandum "Of Understanding on a Strategic Energy Partnership between Ukraine and the European Union in association with the European Atomic Energy Community", available at: http://zakon3.rada.gov.ua/laws/show/984_003-16 (accessed: 10 November 2019).

13. Edwards, J. (2008), "Knowledge management in the energy sector: Review and future directions", International Journal of Energy Sector Management, vol. 2, pp. 2-23.

14. ISO (2019), "ISO and energy", available at: https://www.iso.org/files/live/sites/isoorg/files/store/en/PUB100320.pdf (accessed: 1 October 2019).

15. Pryjmak, V.M. (2018), "Organizational training in project management system". Ekonomika ta upravlinnia pidpryiemstvam, pp. 214-221.

\author{
Smoliar Liubov, Trofymenko Olena \\ International University of Finance, \\ National Technical University of Ukraine \\ "Igor Sikorsky Kyiv Polytechnic Institute"
}

\section{TRANSFORMATION OF THE RENEWABLE ENERGY SECTOR BASED ON KNOWLEDGE MANAGEMENT}

The trends of renewable energy development and peculiarities of knowledge management in this field are investigated in the article. The purpose of the study is to identify trends in the development of renewable energy and features of knowledge management at enterprises in this field. The basic principles at the national and international levels for the development of renewable energy in Ukraine are identified. The structure of electricity production from different sources of generation is investigated. Dynamics of energy consumption based on renewable sources from 2007 to 2018 are analyzed. Based on the dynamics analysis it is established that energy consumption based on wind and solar energy is growing rapidly. It is determined that the facilities of wind energy systems and solar energy systems accounted for 
more than 99\% of installed capacity due to renewable energy sources in Q1 2019. There is an increase in the number of enterprises in the renewable energy sector, which requires the introduction of knowledge management approaches for their further development. The main aspects of knowledge management at the renewable energy enterprises are determined, which are caused by the sectoral features of the functioning of these enterprises. Examples of scientific, technological and managerial knowledge on the example of renewable energy are given. The directions of application of the International Organization for Standardization (ISO) standards in the field of renewable energy are detailed, namely: solar energy, solid biofuels, energy management, hydrogen technologies, environmental management, heat pumps and others. The formation of external networks and the use of IT technologies are of particular importance. The main drivers (driving forces) in knowledge management for realization in the renewable energy enterprises are defined and characterized, namely: knowledge creation, knowledge search, knowledge storage, knowledge exchange, organizational training. The main competences of the modern renewable energy project manager are noted.

Key words: knowledge management, renewable energy, enterprise development.

JEL classification: 